\title{
Rasjonell og sikker farmakoterapi for eldre
}

\author{
Det er sammenheng mellom høy alder og legemiddelrelaterte problemer, men vi mangler god kunnskap \\ om rasjonell farmakoterapi blant eldre.
}

De farmakokinetiske forhold for de fleste legemidler hos eldre over 80 år er i stor grad ukjent. Dette gjelder også digitoksin og digoksin. Den pågående omleggingen av forskrivningspraksis med overgang fra digitoksin til digoksin har så langt gitt mange og til dels alvorlige bivirkninger. En av flere årsaker er kunnskapsmangel.

I Norsk legemiddelhåndbok heter det at digitoksin har en halveringstid på 4-9 døgn (1). I en undersøkelse med eldre med en gjennomsnittsalder på 86,5 år viste det seg at halveringstiden for digitoksin var 25 dager (2). Den anbefalte utvaskingsperioden burde derfor vært 3-4 ganger lengre for noen pasienter enn det som er anbefalt. I en undersøkelse av digoksin hos «yngre» (34-61 år) og eldre pasienter (72-91 år) fant man en dobbelt så lang halveringstid hos de eldre (3). En reduksjon av vedlikeholdsdosen er derfor nødvendig for unngå toksisitet. Også symptomene på bivirkninger endrer seg med alderen. De eldre pasientene får kognitive endringer, sløret syn og arytmi, i tillegg til vekttap, som er vanlig i alle aldersgrupper. Det finnes eksempler på dødsfall som kan knyttes til feiltolking av symptomer på digitalisforgiftning hos svært gamle demente pasienter.

\section{Dysfarmasi}

Hvordan kan vi gi disse eldste eldre en sikrere og mer rasjonell legemiddelbehandling? Vi kan bruke den kunnskapen vi har og etter beste evne ekstrapolere denne.

En god begynnelse er å unngå dysfarmasi, dvs. uhensiktsmessig og irrasjonell bruk av legemidler. Polyfarmasi, dvs. for mange legemidler per sykdom, er en viktig del av dysfarmasi. Takket være utviklingen av medisinsk teknologi og omfattende omsorgstjenester lever de eldre lenger, men de lever også med flere sykdommer på samme tid, noe som kan gjøre det nødvendig å bruke flere legemidler samtidig. Å skille nødvendig og unødvendig polyfarmasi er vanskelig.

Andre eksempler på dysfarmasi er feil legemiddel for en gitt sykdom, feil dose av riktig legemiddel, behandling av bivirkning med et annet legemiddel, uhensiktsmessig administrasjonsform, administrasjon av lege- middel til feil pasient, kombinasjon av legemidler som gir alvorlige interaksjoner. Mye av dette kan unngås med dagens kunnskap.

I tillegg trenger vi ny kunnskap. Mangel på dokumenterbar legemiddelkunnskap basert på kliniske utprøvninger gjelder særlig barn og eldre. Jo yngre barna er, desto større blir savnet av farmakoterapeutisk

\section{«Hos syke eldre som blirbehandlet ihjemmet, kan det være vanskelig å skille symptomer på kronisk eller akutt sykdom fra legemiddel- bivirkninger»}

kunnskap, men det er store etiske utfordringer knyttet til legemiddelutprøvninger hos barn. Det samme gjelder legemiddelutprøvninger hos eldre. Bør man risikere å påføre friske 80-åringer bivirkninger for å få grunnleggende kunnskap? Er det etisk forsvarlig å bruke eldre til å prøve ut legemidler de ikke har behov for? Studiedesign og fortolkning av resultater ved slike studier er ofte vanskelig. Som gruppe har de syke over 80 år ofte multiple legemiddelregimer pga. flere sameksisterende sykdommer. Dette er årsaker til at eldre som oftest blir ekskludert fra legemiddelstudier (4).

\section{Kasuistikk som kunnskapskilde}

Finnes det alternativer til randomiserte, kliniske studier? Vi mener det bør pusses støv av kasuistikken - kasuistikken som metode må oppgraderes som kunnskapskilde. Ved systematisk innsamling og bearbeiding av slik erfaringskunnskap kan man utvikle gode farmakoterapeutiske veiledere for de eldste eldre, mener vi.

Vi må også ta innover oss at flere og flere av de syke eldre blir behandlet i hjemmet.
Tiden det profesjonelle omsorgsapparatet har til å observere og vurdere pasientens helse og livssituasjon generelt, blir stadig mindre. Dermed blir også muligheten til å observere mulige bivirkninger redusert. Hos syke eldre som blir behandlet $i$ hjemmet, kan det være vanskelig å skille symptomer på kronisk eller akutt sykdom fra legemiddelbivirkninger.

Vi ønsker å bidra til rasjonell farmakoterapi og økt pasientsikkerhet for de eldste eldre. Bedre samhandling kan gi de eldste eldre pasientene bedre helse og bedre livssituasjon.

\author{
Camilla Bystad \\ Georg Sager \\ georg.sager@uit.no
}

Camilla Bystad (f. 1984) er medisinstudent ved

Universitetet i Troms $\varnothing$

Forfatter har fylt ut ICMJE-skjemaet og oppgir følgende interessekonflikter: Hun er studentstipendiat lønnet av Skipsreder Tom Wilhelmsens stiftelse.

Georg Sager (f. 1951) er avdelingsoverlege ved Avdeling for klinisk farmakologi, Universitetssykehuset Nord-Norge, og professor i medisinsk farmakologi og toksikologi ved Universitetet i Tromsø.

Forfatter har fylt ut ICMJE-skjemaet og oppgir ingen interessekonflikter.

Litteratur

1. Norsk legemiddelhåndbok for helsepersonell 2012. Oslo: Foreningen for utgivelse av Norsk legemiddelhåndbok, 2010.

2. Bøhmer T, Røseth A. Prolonged digitoxin half-life in very elderly patients. Age Ageing 1998; 27: $222-4$.

3. Cusack B, Kelly J, O'Malley K et al. Digoxin in the elderly: pharmacokinetic consequences of old age. Clin Pharmacol Ther 1979; 25: 772-6.

4. Kristjansson SR, Wyller TB. Avslutning av forebyggende legemiddelbruk hos eldre. Tidsskr Nor Legeforen 2010; 130: 1726-8.

Mottatt 22.10. 2012, første revisjon innsendt 12.11 . 2012, godkjent 13.12. 2012. Medisinsk redaktør Petter Gjersvik.

Publisert først på nett. 